УДК 330.1:658

Карлін M.І., д.е.н., професор

Karlin M. Doktor of Economic Sciences, Professor https://orcid.org/0000-0002-1421-1066

Івашко О.А., к.е.н., доцент

Ivashko O. Candidate of Economic Sciences, Associate Professor https://orcid.org/0000-0003-2950-0474

\title{
ЗЕЛЕНІ ФІНАНСИ ЯК НОВИЙ НАПРЯМ ЗАЛУЧЕННЯ ІНВЕСТИЦІЙ В ЕКОНОМІКУ УКРАЇНИ
}

\author{
Східноєвропейський національний університет імені Лесі Українки
}

У відповідності до міжнародних угод (як то Угода про асоціацію з СС), Україна взяла на себе зобов'язання побудувати зелену еокноміку. Проте виконання такого завдання передбачає не тільки реалізацію необхідних реформ на рівні реальної економіки, а й докорінну перебудову фінансової системи. Така система повинна не тільки бути готовою до посилення впливу нефінансових ризиків, а й забезпечити мобілізацію необхідних обсягів зелених фінансів. Так, за свідченнями провідного дослідницького та консалтингового центру DIW Econ, Україні потрібні будуть більше 200 млрд євро для досягнення поставленої мети.

У статті висвітлено актуальні питання щодо напрямів «зеленого» перенаправлення потоків капіталу з метою модернізації фінансової системи та іï переорієнтації на забезпечення сталого розвитку. Встановлено, що виникає потреба у використанні таких термінів як «екологічні фінанси», «екологічне інвестування» або «інвестування, пов'язане 3 кліматичними змінами». Розглянуто особливості обігу “зелених” облігацій як новітніх інструментів екологічного інвестування.

У результаті проведених досліджень встановлено, що шлях до створення «зеленої економіки» набуває дедалі більшої актуалізації, але досягнення поставленої мети неможливе без чіткого усвідомлення наявних проблем і вироблення стратегій їх подолання. Широке використання інструментів екологічного інвестування може дати певний позитивний ефект, але слід враховувати їх підвищену вартість у порівнянні 3 традиційними інвестиційними інструментами. Зокрема, це стосується таких елементів «зелених» фінансів, як «зелений» тариф, «зелені облігації», «теплі» кредити тощо, які також доцільно розглядати як структурні елементи екологічного інвестування.

Ключові слова: «зелені» фінанси, екологічні фінанси, екологічне інвестування, «зелені облігащії», «зелені» банки, «зелений» тариф.

\section{GREEN FINANCE AS A NEW DIRECTION OF INVESTMENT IN UKRAINE}

\section{Lesya Ukrainka Eastern European National University}

In accordance with international agreements (such as the Association Agreement with the EU), Ukraine has committed itself to building a green economy. However, the implementation of such a task involves not only the implementation of the necessary reforms at the level of the real economy, but also a radical restructuring of the financial system. Such a system should not only be ready to increase the impact of non-financial risks, but also to ensure the mobilization of the necessary amounts of green finance. Thus, according to the leading research and consulting center DIW Econ, Ukraine will need more than 200 billion euros to achieve this goal.

The article highlights current issues in the areas of "green" redirection of capital flows in order to modernize the financial system and its reorientation to ensure sustainable development. Terms such as "environmental finance", "environmental investment" or "climate change investment" have been identified. Peculiarities of green bonds circulation as the newest instruments of ecological investment are considered.

As a result of the conducted researches it is established that the way to creation of "green economy" becomes more and more actual, but achievement of the set purpose is impossible without accurate awareness of existing problems and working out of strategies of their overcoming. Extensive use of environmental investment instruments can have some positive effects, but their increased cost should be taken into account compared to traditional investment instruments. In particular, this applies to such elements of "green" finance as "green" tariff, "green bonds", "warm" loans, etc., which should also be considered as structural elements of environmental investment.

Keywords: "Green" finance, environmental finance, environmental investment, "green bonds", "green" banks, "green" tariff. 
Постановка проблеми у загальному вигляді 3 її важливими науковими та практичними завданнями. На сьогоднішній день досить актуальним є вивчення тенденцій модернізації світової фінансової системи за рахунок створення, розвитку та запровадження концепцій іiі екологізації. За оцінками ЮНЕП для досягнення цілей сталого розвитку необхідний чималий обсяг фінансування - 5-7 трлн дол. США на рік, що знижує привабливість та придатність традиційних методів фінансового забезпечення. Тому виникає потреба в розробці напрямів «зеленого» перенаправлення потоків капіталу 3 метою модернізації фінансової системи згідно умов забезпечення сталого розвитку. Разом 3 тим, виникає потреба у 3'ясуванні таких термінів як «зелені» фінанси, «екологічні фінанси», «екологічне інвестування» або «інвестування, пов'язане 3 кліматичними змінами». Вважається, що вперше сфера «зелених» чи «екологічних» фінансів була визначена Річардом Сандором у 1992 році у розробленій навчальній програмі для студентів Колумбійського університету. Проте i до сьогодні не сформульовано остаточного визначення так званих «зелених» або ж «екологічних» фінансів та їх структури.

Аналіз останніх досліджень, у яких започатковано вирішення проблеми. Значний внесок у дослідження різних аспектів функціонування "зелених" фінансів, зробили такі зарубіжні та українські вчені, як В. Борейко, Е. Вайцзеккер, І. Вахович, В. Голян, О. Губанова, Б. Данилишин, Г. Дейлі, І. Запатріна, С. Козьменко, В. Кравців, Д. Лижін, Б. Порфір'єв, Б. Рубцов, Р. Сандор, О. Сохацька, І. Сторонянська, А. Сундук, Дж. Сьєберт, Ю. Туниця, Дж. Фарлей, М. Хвесик, Є. Хлобистов та ін. Віддаючи належне високому рівню наукових робіт зазначених вчених варто відмітити, що не вистачає досліджень комплексного впливу ролі «зелених» фінансів як інструменту екологізації фінансової системи держави, Крім того, поки не вистачає досліджень комплексного впливу ролі територіальних громад на становлення «зеленої» економіки на місцях. Тому необхідне активне підключення територіальних громад різного рівня шляхом їх фінансового стимулювання до побудови «зеленої» економіки в Україні.

Мета і завдання дослідження. Метою статті є уточнення змісту та структури «зелених» фінансів у широкому i вузькому розумінні слова та обгрунтування необхідності розширення сфери інвестування у «зелену» економіку в Україні за рахунок використання розгалуженої системи інструментів екологічного інвестування 3 урахуванням досвіду провідних країн світу. Завданнями дослідження є: визначення змісту та структури «зелених» фінансів та екологічних фінансів; уточнення співвідношення таких понять як «зелені» фінанси та екологічні фінанси; виявлення структурних елементів екологічного інвестування; аналіз можливостей застосування окремих інструментів екологічного інвестування, що використовуються у провідних країнах світу на державному та регіональному рівнях, в Україні.

Виклад основного матеріалу дослідження 3 повним обгрунтуванням отриманих наукових результатів. «Зелені» або ж екологічні фінанси передбачають широкий спектр фінансових засобів та інструментів для технологій, проектних робіт та галузей в цілому, що мають екологічне спрямування. Саме тому їх можна розглядати як у вузькому, так і в широкому розумінні.

У вузькому розумінні екологічні фінанси є сукупністю фінансових продуктів і послуг, розробка і реалізація яких спрямована на зниження ризику екологічного i кліматичного розвитку. Сюди можна віднести фінансування програм та проектів щодо збалансованого природокористування, виробництво екологічних товарів і послуг, розвиток технології низьковуглецевого виробництва та відповідне зниження викидів у атмосферу парникових газів [3]. У широкому значенні трактування екологічних фінансів охоплює додатково механізми фінансового стимулювання або субсидування відновлюваної енергетики, фінансові установи, що займаються екологічними інвестиціями, забезпечують їх фінансування та хеджування, передбачає фінансування як державне, так і приватного сектору та загалом ефективне управління у фінансовій системі щодо екологічних ризиків. Загалом, враховуючи однакову спрямованість 
«зелених» та екологічних фінансів щодо забезпечення умов сталого розвитку, їх можна розглядати як тотожні поняття. Водночас, за характеристикою структурних елементів вони мають певні відмінності, оскільки структура екологічних фінансів має ширшу кількість компонентів, ніж структура «зелених» фінансів, які ще не до кінця з'ясовані. Пандемія коронавірусу у першій половині 2020 р. показала, що людству прийдеться шукати нові підходи до забезпечення сталого розвитку на глобальному рівні, ніж ті, які зараз використовуються при здійсненні «зеленого» фінансування. Одним із таких напрямів стає глобальне інвестування у розробку наукових програм щодо пошуку засобів протидії новим вірусам, до негативних наслідків яких людство поки не готово.

Аби досягти глобального економічного зростання необхідно враховувати два найважливіші фактори: інновації та інклюзивність. Саме вони відіграють провідну роль на шляху до інтеграції у світову економіку. Важливим етапом $є$ і реформування наявної фінансової системи держави. У квітні 2016 року міністрами фінансів та керівниками центральних банків G20 було прийнято рішення, в яких висвітлено і схвалено дев'ять пріоритетних напрямів структурних реформ, розглянуто створення системи показників оцінки та контролю за їх реалізацію 3 метою подальшого вдосконалення фінансової системи. Сюди належать:

- заохочення інновацій;

- поліпшення інфраструктури;

- розвиток конкуренції та сприятливих умов;

- удосконалення і зміцнення фінансової системи;

- просування податкової реформи;

- підвищення екологічної стійкості;

- сприяння всебічному зростанню;

- сприяння розвитку торгівлі та інвестиційної відкритості;

- просування реформи ринку праці, рівень освіти і навичок.

Дані принципи лідерів G20 у Програмі структурної реформи спрямовані на покращення та зміцнення фінансової системи держави. Зокрема вони повинні позитивно вплинути на фінансову стабільність, зростання інновацій, розширити систему традиційного банківського фінансування і запобігти системним ризикам, що властиві діяльності фінансових установ.

Варто зазначити, що загальнодержавна програма адаптації законодавства України до законодавства Європейського Союзу визначає методи досягнення Україною критеріїв набуття членства в ЄС та розвиток у провідних сферах. Ця програма є недієвою та не виконується у визначених законом формах та термінах. Саме невиконання імплементації вимог і уповільнює інтеграцію України до Європейського Союзу. Відповідно також одним із завдань G20 у їх стратегічній меті економічного зростання є розширення сфери застосування «зеленого» фінансування. 3 цією метою створено Дослідницьку групу зелених фінансів GFSG (Green Finance Study Group), метою якої є вироблення варіантів вирішення цієї проблеми.

GFSG наводить своє трактування «зелених» фінансів. Вони розглядаються як фінансування інвестицій, які мають екологічні переваги у досягненні сталого розвитку, наприклад скорочення рівня забрудненості природних ресурсів, скорочення викидів в атмосферу парникових газів, зростання ефективності використання енергії, полегшення адаптації до кліматичних змін [3]. Зокрема, зелені фінанси охоплюють велику кількість фінансових інституцій та їх активів, державне і приватне інвестування та ефективне управління 3 метою зниження екологічних ризиків у фінансовій системі в цілому. Відповідно, всі ці складові можна віднести й до структурних елементів екологічних фінансів.

Не дивлячись на те, що вже досягнуто певного прогресу у подоланні екологічних ризиків, частка банківського кредитування як зеленого фінансування в світовій практиці все ж $є$ невисокою. Близько 1\% облігацій виступають у формі «зелених», а менше 1\% 
активів інфраструктури $\epsilon$ екологічно чистими. Розвинені країни продовжують вдосконалювати національні законодавства та, зокрема, приділяють все більшу увагу розширенню можливих варіантів розвитку зеленого фінансування. Воно, в свою чергу, доповнює загальне інвестування з фінансового сектору. Такими напрямами можуть бути розширення варіантів кредитування та інвестування, доступність екологічної інформації, регулювання напрямів зелених кредитів за допомогою зелених облігацій, функціонування інвестиційних трастів як зеленої інфраструктури тощо. Важливо також використати такий елемент екологічного інвестування, як «теплі» кредити. Їх особливість полягає в тому, що кошти на їх погашення виділяються державою, органами місцевого самоврядування, ОСББ й мешканцями будинків, які підлягають утепленню чи модернізації системи обігріву та електропостачання. Участь мешканців будинків у такому кредитуванні дозволяє уникнути різного роду корупційних схем.

Дослідження Міжнародного енергетичного агентства (MEA), Світового банку, Організації економічного співробітництва i розвитку (ОЕСР) та Всесвітнього економічного форуму визначили спрямування значних коштів зелених проектів у такі галузі, як будівництво, енергетика, інфраструктура, водні ресурси, відходи тощо.

На сучасному етапі розвитку нашої держави важливу роль відіграє вивчення досвіду провідних країн світу. За таких умов важливо пам'ятати, що світовою ціллю $є$ досягнення «синьої економіки», тобто тієї довершеної форми економіки, яка передбачала б не просто раціональне та виважене використання наявних ресурсів суспільством, а й керування власними наявними можливостями без обмеження в просторі та часі можливостей інших. Основне зобов'язання України, яке вона взяла на себе відповідно до міжнародних умов (Угода про асоціацію з СС) - побудова початкової «зеленої економіки». За даними дослідницького та консалтингового центру DIW Econ Україні для поставленої мети необхідно не менше 200 млрд євро. Зрозумілим стає, що впоратися з таким обсягом інвестицій наша країна не в змозі, оскільки маємо сьогодні на рахунку значні обсяги державного боргу. Тому пріоритетним напрямком для України $\epsilon$ необхідність створення умов щодо залучення зелених фінансів зі світових ринків, що особливо важливо в умовах світової кризи, яка розпочалася з початком 2020 p.

Щодо закордонного досвіду, то варто зазначити досвід Люксембургу як лідера номер один на світовому ринку зелених фінансів. Сучасний зелений фінансовий центр був створений за ініціативи уряду Люксембургу, Свропейського інвестиційного банку, консалтингових компаній та представників фінансового ринку. Зокрема, було створено Акселератор, який об'єднав такі складові: Люксембурзьку фондову біржу, Green Flag (Сертифікація зелених фінансових інструментів), спільну інвестиційну платформу уряду Люксембургу та Європейського інвестиційного банку. В результаті це дало можливість випускати на одному майданчику майже половину всіх зелених облігацій та вільно користуватися на одній платформі і облігаціями сталого розвитку і облігаціями соціального впливу.

В Україні ж «зелені облігації» можуть стати доволі перспективним фінансовим інструментом, для залучення інвестицій в проекти енергетичної сфери виробництва. Це безпосередньо дозволить вдосконалити як і відновлювальну енергетику, так і підвищити саму енергоефективність. Сукупний обсяг розміщення «green bonds» на світовому ринку у 2017 р. був у 2 рази більшим ніж у 2016 році і в 180 разів більшим ніж 10 років назад. Тому Україна має розвивати такі ж тенденції, тим більше багато фінансових установ все більше проявляють цікавість до даної сфери інвестування [5].

Для України важливим елементом екологічного інвестування можуть стати й «зелені» кредити так званих «зелених» банків, що отримують розповсюдження в окремих регіонах розвинутих країнах. Хоча вони надають менші ставки за депозитами, ніж традиційні комерційні банки, але їх перевага полягає в тому, що вони кредитують насамперед екологічні проекти в регіонах, де проживають їх основні вкладники. Вигода для останніх полягає у кращих екологічних умовах проживання для них. Певний досвід надання подібних кредитів (насамперед, «теплих» кредитів) в Україні має державний 
«Укргазбанк», але кошти на екологічні інвестиції йому поки виділяють переважно міжнародні фінансові структури.

Важливим питанням у вирішенні екологічних проблем в Україні є переробка сміття. На сміттєзвалищах вже накопичено більше 50 млн тонн відходів. За статистикою, кожного року дана цифра збільшується щонайменше на 15 млн тонн. Причиннонаслідковий зв'язок веде до суттєвих ризиків як екологічного стану суспільства, так і до економічних загроз. Та виходячи з сучасного розвитку технологічної переробки саме ця галузь може бути перспективною, оскільки питання виробництва відновлювальної енергії є актуальним як національним так і іноземним інвесторам. В цьому напрямку важливо приділити увагу використанню виробництва комбінованого тепла та електроенергії - когенерації. Досвід у сфері енергетики, а зокрема щодо когенераційних систем можемо запозичити у Німеччини. Високоефективному розвитку когенерації сприяють сьогодні Директиви 2004/8 та 2012/27/ЄС, які здійснюють наближення українського законодавства до законодавчих норм ЄС. За 2017 рік в Україні загальний обсяг виробленої електроенергії склав 44 млрд кВТ-год, з якої 38\% склали ТЕС та когенераційні установки. Проаналізувавши оперативні дані Науково-технічної спілки енергетиків та електротехніків України маємо такі характеристики паливноенергетичної сфери (таблиця 1).

Таблиця 1

Динаміка показників роботи енергетичного комплексу України за січень-березень 2017/2018 року

\begin{tabular}{|c|c|c|c|}
\hline Обсяг виробництва електричної енергії & $\begin{array}{c}01.01-31.03 \\
2017 \text { p, млн } \\
\text { кВТ* }^{*}\end{array}$ & $\begin{array}{c}01.01-31.03 \\
2018 \text { р, млн } \\
\text { кВт* }^{*}\end{array}$ & $\begin{array}{c}\text { Показник } \\
\text { результативності, \% }\end{array}$ \\
\hline $\begin{array}{l}\text { 1. Електростанціями, що входять до ОЕС } \\
\text { України }\end{array}$ & 42909,9 & 44542,0 & $\uparrow$ на 3,8 \\
\hline $\begin{array}{l}\text { 2. Тепловими електростанціями } \\
\text { енергогенеруючих компаній }\end{array}$ & 11111,1 & 13188,9 & $\uparrow$ на 18,7 \\
\hline $\begin{array}{l}\text { 3. Теплоелектроцентралями } \\
\text { когенераційними установками }\end{array}$ & 4058,4 & 4425,2 & $\uparrow$ на 9,0 \\
\hline $\begin{array}{ll}\text { 4. Гідроелектростанціями } & \text { та } \\
\text { гідроакумулюючими електростанціями }\end{array}$ & 3177,7 & 4035,3 & $\uparrow$ на 27,0 \\
\hline $\begin{array}{l}\text { 5. Альтернативними джерелами (BEC, } \\
\text { CEC, біомаса) }\end{array}$ & 411,5 & 532,6 & $\uparrow$ на 29,4 \\
\hline
\end{tabular}

Інформаційно-аналітичне дослідження стану паливно-енергетичного комплексу України та наведені основні показники роботи паливно-енергетичного комплексу за січень-березень 2018 року висвітлюють позитивні риси зростання енергетичної галузі. Саме такий шлях розвитку є перспективним для даного сектору виробництва. Особливо високоефективне використання когенерації забезпечить оптимальне управління відходами та вдосконалення енергетичної системи, перспективою якої буде відмова від традиційних енергетичних джерел [11].

Перебудова потужностей енергетичної галузі неможлива без внесення змін у систему фінансових трансакцій. Зв'язок між даними сферами пояснюється європейським та світовим ринком, де існує широке поширення такої технології як Blockchain. Базується дана технологія на проекті Enerchain, який об'єднує лідируючих виробників електроенергії та іiї споживачів у таких країнах як Німеччина, Франція, Австрія (ENGIE, OMV, E-On iн.) [4]. Технологія Blockchain представляє платформу, яка полегшує управління мережею фінансових трансакцій паливно-енергетичної сфери, яка в свою чергу продукує збільшення частки «зеленої енергії» і допомагає здійснити купівлю- 
продаж без посередників. Приєднання до згаданої платформи дало б нам змоги діяти на ринку із суб'єктами міжнародного масштабу.

Функціонування зеленої економіки прямо залежить від джерел іiі фінансування, чим в даному випадку виступають «зелені облігації». Створенню умов їх використання сприяє наявна нормативно-правова база Угоди про асоціацію з ЄС. Функціонування та обіг зелених облігацій забезпечили б як ефективну мобілізацію фінансових ресурсів, так і пришвидшило б євроінтеграційні процеси України. За підсумками 2017 року ринок зелених облігацій України становив 155 млрд. дол. За прогнозами учасників ринку до 2020 року очікується, що частка зелених облігацій буде становити 10-15\% від усієї маси облігаційного потоку. Та проблемою міжнародного рівня $є$ те, що тільки близько $30 \% 3$ них $\epsilon$ сертифікованими фінансовими інструментами, а решта виступає левовою частиною і ховається за характерними ознаками зелених проектів. Інвестування коштів, які мобілізовані за допомогою зелених облігацій, спрямовані більшою мірою на фінансування транспортної інфраструктури, а не у сферу енергетики.

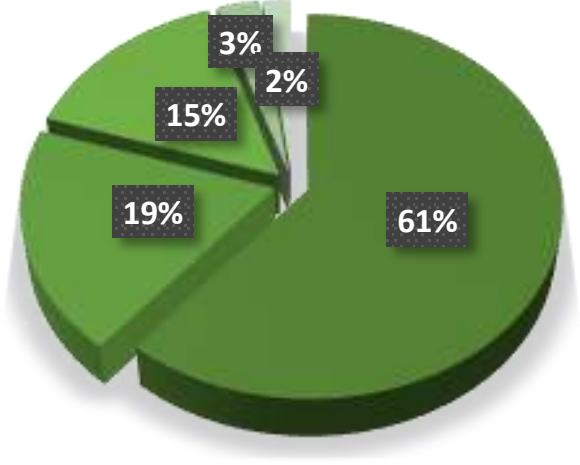

$$
\begin{aligned}
& \text { - Транспорт } \\
& \text { Енергетика } \\
& \text { Ш Мультисекторальне } \\
& \text { Вода } \\
& \text { Будівництво }
\end{aligned}
$$

2017 році

Рис. 2. Фінансування міжнародних проектів за допомогою зелених облігацій у *складено за даними Climate Bonds Initiative

Перспективним напрямком інвестування в Україні $\epsilon$ також екологічний транспорт. Його впровадження значною мірою дозволило б скоротити та мінімізувати вуглецеві викиди у атмосферу. Українська компанія «Богдан» має перспективне виробництво спеціального електричного транспорту для країн $€ С$, які наразі проявляють чималий інтерес до екологічної техніки. До прикладу, для данської компанії Banke Electromotive виготовлено електромашину ERCV27, яка призначена для механізованого завантаження твердих побутових відходів. Застосовуватиметься даний автомобіль у різних містах Європейського Союзу. Після 2025 року у країнах СС планують повністю заборонити авто з дизельними двигунами, а дана техніка має стати альтернативним аналогом і вже сьогодні відповідає поставленим стандартам і європейським екологічним нормам. Корпорація «Богдан» виготовляе найсучасніші тролейбуси для Європи, електробуси для Польщі та Чехії, кузови електробусів для Франції. Водночас наша держава не виявляє інтересу наситити власний національний ринок подібною технікою, причиною чого $є$ відсутність інвестиційних ресурсів. Даний етап заміни застарілих машин, які несуть величезну загрозу довкіллю, є важливим для нас шляхом, перш за все, заради збереження екології та для інтеграції за європейськими стандартами [1].

Суттєвою проблемою в екологічному інвестуванні в Україні є пошук державою додаткових фінансових ресурсів, щоб забезпечити виплати за «зеленим» тарифом (він у нас найвищий в Свропі) для виробників відновної енергії. Держава повинна знайти такі варіанти, які б дозволили їй виконати свої зобов'язання перед виробниками відновної енергії (інакше Україна отримає сотні звернень в суди від цих виробників, як це вже 
відбулося в Іспанії). Одним із них повинен стати перехід до аукціонної торгівлі відновною енергією, як це робиться у ряді розвинутих країн світу. Також важливо за допомогою «зеленого» тарифу стимулювати розвиток відновної енергетики насамперед у домогосподарствах населення в тих регіонах, де існує нестача енергії. Для нових великих сонячних (СEC) та вітрових електростанцій (BEC), яких в Україні вже побудовано достатньо, доцільно з 2021 р. відмінити «зелений» тариф та зобов'язати їх власників та інвесторів побудувати так звані енергосховища, в які буде направлятися надлишок енергії від СЕС і ВЕС у весняно-літній період. Крім того, владі України необхідно виділити балансуючі потужності на ТЕС і ГЕС для регулювання подачі електроенергії від СЕС і ВЕС, в осінньо-зимовий період, коли іiі виробництво суттєво знижується. Регіонам України, а також об'єднаним територіальним громадам доцільно залишати частину регресивної субвенції для підтримки балансуючих потужностей для ефективного функціонування підприємств відновної енергетики.

Висновки. Шлях до створення «зеленої економіки» набуває дедалі більшої актуалізації, але досягнення поставленої мети неможливе без чіткого усвідомлення наявних проблем i вироблення стратегій їх подолання. Широке використання інструментів екологічного інвестування може дати певний позитивний ефект, але треба враховувати їх підвищену вартість у порівнянні 3 традиційними інвестиційними інструментами. Зокрема, це стосується таких елементів «зелених» фінансів, як «зелений» тариф, «зелені облігації», «теплі» кредити тощо, які також доцільно розглядати як структурні елементи екологічного інвестування. Загалом, на даному етапі розвитку фінансової системи України доцільно розглядати «зелені» фінанси та екологічні фінанси як тотожні поняття, розуміючи, що з часом структура останніх стан ширше, ніж структура «зелених» фінансів. Так, важливим етапом у розвитку екологічного фінансування може стати створення спеціальної агенції, яка б могла надавати спеціальні знаки фінансовим інструментам (дозволи на викиди парникових газів, сертифікати енергоефективності, гарантії походження, водні та інші екологічні сертифікати), та агенції, яка б займалася страхуванням кліматичних ризиків на державному рівні.

\section{Список бібліографічного опису}

1.«Богдан» презентував у Луцьку першу електровантажівку для ЄC, 2018. URL: https://konkurent.in.ua (дата зверененя: 22.03.2020).

2.Бояр А. О. Трансформація бюджетної моделі ЄС в умовах глобальної фінансової турбулентності: монографія. Луцьк. ВежаДрук. 2014. 256 с.

3.Вплив «зелених фінансів» на економічні, соціальні та екологічні наслідки: виклики сьогодення, 2016. URL: http://nauditor.com.ua/ru/component/na_archive/1490.html?view=material (дата зверененя: 20.12.2019).

4.Зелена економіка та зелені фінанси - больові точки для України, 2018. URL: https://delo.ua/business/zelena-ekonomika-tazeleni-finansi-bolovi-tochki-346686/ (дата зверененя: 28.04.2020).

5. «Зелені облігації» - перспективний інструмент залучення інвестицій у проекти «чистої» енергетики в Україні, 2018. URL: https://www.kmu.gov.ua/news/zeleni-obligaciyi-perspektivnij-instrument-zaluchennya-investicij-u-proekti-chistoyi-energetiki-vukrayini (дата зверененя: 28.04.2020).

6.Кліматичні фінанси: кол. моногр. / авт. кол. М. І. Карлін, Н. В. Проць, І. О. Цимбалюк та [ін]; за заг. ред. д-ра екон. наук, проф. М. І. Карліна. Луцьк, 2017. 184 с.

7. Порфирьєв Б. Н. «Зеленые» тенденции в мировой финансовой системе. Мировая экономика и международные отношения. 2016. № 9. С. 5-16.

8.Сундук А. Аналіз змістовних характеристик фінансово-економічного регулювання у сфері природокористування. Економіст. 2017. № 12. С. 31-34.

\section{References}

1.«Bogdan» prezentuvav u Lucz`ku pershu elektrovantazhivku dlya YeS, 2018. URL: https://konkurent.in.ua. [in Ukrainian] (Last accessed: 22.03 .2020$)$.

2. Boyar A. O. Transformaciya byudzhetnoyi modeli YeS v umovax global’noyi finansovoyi turbulentnosti: monografiya. Lucz`k. Vezha-Druk. 2014. 256 s. [in Ukrainian].

3.Vply`v «zeleny`x finansiv» na ekonomichni, social`ni ta ekologichni naslidky`: vy`kly`ky` s`ogodennya, 2016. URL: http://nauditor.com.ua/ru/component/na_archive/1490.html?view=material [in Ukrainian] (Last accessed: 20.12.2019).

4.Zelena ekonomika ta zeleni finansy` - bol'ovi tochky dlya Ukrayiny, 2018. URL: https://delo.ua/business/zelena-ekonomika-tazeleni-finansi-bolovi-tochki-346686/ [in Ukrainian] (Last accessed: 28.04.2020).

5. «Zeleni obligaciyi» - perspekty`vny`j instrument zaluchennya investy`cij u proekty` «chy`stoyi» energety`ky`v Ukrayini, 2018. URL: https://www.kmu.gov.ua/news/zeleni-obligaciyi-perspektivnij-instrument-zaluchennya-investicij-u-proekti-chistoyienergetiki-v-ukrayini [in Ukrainian] (Last accessed: 28.04.2020).

6. Klimaty`chni finansy`: kol. monogr. / avt. kol. M. I. Karlin, N. V. Procz`, I. O. Cy`mbalyuk ta [in]; za zag. red. d-ra ekon. nauk, prof. M. I. Karlina. Lucz k, 2017. 184 s. [in Ukrainian].

7.Porfy'r'yev B. N. «Zelenыe» tendency'y`v my'rovoj fy`nansovoj sy`steme. My`rovaya эkonomy`ka y` mezhdunarodnыe otnosheny'ya. 2016. \# 9. S. 5-16. [in Ukrainian]. 
8. Sunduk A. Analiz zmistovny`x xaraktery`sty`k finansovo-ekonomichnogo regulyuvannya u sferi pry`rodokory`stuvannya. Ekonomist. 2017. \# 12. S. 31-34. [in Ukrainian].

Дата подання публікації 18.06 .2020 p.

УДК 336.02:658.15

Купира М.I., к.е.Н., доцент

Kupyra M. Candidate of Economic Sciences, Associate Professor https://orcid.org/0000-0002-8279-7628

Киришко М.В., студент

Kyryshko M. Student

\title{
ФОРМУВАННЯ ФІНАНСОВОЇ СТРАТЕГІЇ В СИСТЕМІ ЗАБЕЗПЕЧЕННЯ КОНКУРЕНТОСПРОМОЖНОСТІ ПІДПРИЕМСТВА
}

\author{
Луцьький національний технічний університет
}

У статті доведено, що формування фінансової стратегії як основи стійкого та конкурентоспроможного розвитку у довгостроковій перспективі вимагає чітко побудованого алгоритму 3 врахуванням сучасних тенденцій. Встановлено, що під фінансовою стратегією в системі забезпечення конкурентоспроможності підприємства важливо трактувати загальний план окреслення точковості фінансових цілей та завдань на довгострокову перспективу через формування фінансових ресурсів у векторному напрямку фінансовою стійкості.

Проведено теоретичний розбір сутнісного наповнення фінансової стратегії в процесі формування, реалізації та коригування 3 виділенням структурних елементів фінансової стратегії в частині результативності.

Розроблено архітектуру формування фінансової стратегії в системі забезпечення конкурентоспроможності через матричний аналіз та фінансовий ефект.

Доведено, що фінансова стратегія в частині результативності діє через принципи та етапність щодо формування і впровадження та працює за виведеним алгоритмом: Управління $=$ капітал + активи + інвестиції + грошові кошти+ прибуток + ризики. Узгодженість та ефективність управління на кожному етапі створює вектор прибутковості в процесі гнучкої фінансової політики. В першу чергу, в систему закладають достатній обсяг фінансових ресурсів, методи ефективності використання капіталу, оптимізація його структури та швидке реагування й нейтралізація ризиків на довгострокову перспективу.

Запропоновано матрицю вибору фінансової стратегії в частині ефективного стратегічного управління підприємства через синергію та дисбаланс 3 визначеним рівнем ефективності кожного структурного елементу та розраховано фінансовий ефект від вбудованих інноваційних інструментів у фінансову стратегію, який лише підсилить конкурентні позиції підприємства на ринку.

Фактично, фінансова стратегія є тією основою, яка забезпечує векторне фінансове підгрунтя для фінансово-економічного розвитку в частині нарощення прибутковості. Ї̈ї ефективність окреслюється моментами, за яких стратегічні цілі грунтуються на реальних фінансових показниках та можливостях підприємства, чіткій системі управління, гнучкості та прозорості.

Ключові слова: фінансова стратегія, стратегічне управління, ефективність, результат, підприємство, прибуток, гнучкість, прозорість, системність.

\section{FORMATION OF FINANCIAL STRATEGY IN THE SYSTEM OF PROVIDING OF COMPETITIVENESS OF ENTERPRISES}

\section{Lutsk National Technical University}

The formation of financial strategy as a basis for sustainable and competitive development in the long-term requires an algorithm based on current trends proved in the article. Installed, that the financial strategy in the system of providing competitiveness of enterprise is a general plan of lineation financial goals and tasks on a long-term through forming of financial resources in the vectors direction of financial stability. 